\title{
Effect of thimerosal on thyroid hormones metabolism in rats
}

\section{Thiago U Pantaleão', Andrea C F Ferreira',2, Maria C S Santos', Álvaro S P Figueiredo', Ruy A N Louzada', Doris Rosenthal', Denise P Carvalho' and Vânia M Corrêa da Costa'}

${ }^{1}$ Laboratório de Fisiologia Endócrina Doris Rosenthal, Instituto de Biofísica Carlos Chagas Filho, Universidade Federal do Rio de Janeiro, Rio de Janeiro, Brazil

${ }^{2}$ NUMPEX, Pólo de Xerém, Universidade Federal do Rio de Janeiro, Rio de Janeiro, Brazil
Correspondence

should be addressed

to V M Corrêa da Costa

Email

vmccosta@biof.ufrj.br

\begin{abstract}
Mercury seems to exert an inhibitory effect on deiodinases, but there are few studies using Thimerosal (TM) as the mercury source. We aimed to elucidate the effect of TM on thyroid hormones peripheral metabolism. Adult Wistar female rats received $0.25 \mu \mathrm{g}$ or $250 \mu \mathrm{g} \mathrm{TM} / 100 \mathrm{~g} \mathrm{BW}$, IM, twice a week, for a month. We evaluated serum total $T_{3}$ and $\mathrm{T}_{4}$, D1 activity using ${ }^{125} \mathrm{I}-\mathrm{r} \mathrm{T}_{3}$ as tracer, and D2 activity using ${ }^{125} \mathrm{I}-\mathrm{T}_{4}$. NADPH oxidase activity was measured by Amplex-red/HRP method and mRNA levels by real time PCR. Serum $T_{4}$ was increased and $T_{3}$ decreased by the greatest dose of TM. Even though D1 activity in pituitary and kidney was reduced by the highest dose of TM, hepatic D1 activity and D1 mRNA levels remained unchanged. D2 activity was also significantly decreased by the highest dose of TM in all CNS samples tested, except cerebellum, but D2 mRNA was unaltered. mRNA levels of the tested NADPH oxidases were not affected by TM and NADPH oxidase activity was either unaltered or decreased. Our results indicate that TM might directly interact with deiodinases, inhibiting their activity probably by binding to their selenium catalytic site, without changes in enzyme expression.
\end{abstract}

\author{
Key Words \\ thimerosal \\ - thyroid function \\ - iodothyronine deiodinases
}

\section{Introduction}

For many years, mercury has been used in a wide variety of human activities and has been identified as a factor exerting a range of harmful neurological and cognitive effects in humans and experimental animals, and is implicated in the etiology of a number of neuropsychiatric disorders. There are three categories of mercury compounds: organic, inorganic, and elemental (1). The major environmental organic compounds of mercury include ethylmercury (Et-Hg) and methylmercury (Met-Hg) (2). At present, humans are mostly exposed to mercury through the consumption of mercurycontaminated fish, the administration of vaccines containing thimerosal (ethyl-mercury thiosalicylate, used as preservative in some vaccines administered to mothers and infants), metallic mercury from dental amalgam fillings, and cinnabar, a naturally occurring mineral consisting primarily of mercury sulphide, used in the traditional Chinese medicine $(1,3)$.

Thyroid hormones $(\mathrm{TH})$ play an important role in the development and differentiation of several tissues. In the central nervous system, thyroid hormones are critical for the survival, proliferation, migration, and arborization of neurons (4). As aforementioned, mercury produces important deleterious effects on central nervous system. In the brain, most nuclear triiodothyronine $\left(\mathrm{T}_{3}\right)$ is locally produced from the prohormone thyroxine $\left(\mathrm{T}_{4}\right)$ by type 2 iodothyronine deiodinase (D2) (5). Since deiodinases regulate the metabolism of thyroid hormones, they are key determinants of $\mathrm{TH}$ concentration in the serum and in the different tissues (6). http://www.endocrineconnections.org
DOI: $10.1530 /$ EC-17-0220
() 2017 The authors Published by Bioscientifica Ltd
This work is licensed under a Creative Commons Attribution-NonCommercial-NoDerivatives 4.0 International License. 
Mercury seems to exert an inhibitory effect on iodothyronine deiodinases activity. Mori and coworkers showed that MetHg inhibited D2 activity in both mouse neuroblastoma cell line (7) and rat pituitary tumor cell line (8). In mice, maternal exposure to methylmercury was able to inhibit D3 activity in the brain of newborns, but D2 activity was not affected (9) Sulkowski and coworkers have recently reported a decrease in cerebellar D2 activity following exposure to thimerosal during perinatal period in SHR rats (2).

The mechanisms by which mercury inhibits deiodinase activity have not been clarified. Deiodinases contain selenocysteine in the catalytic site (10). This amino acid is essential for the deiodination reaction and can be a target for $\mathrm{MeHg}$, preventing normal enzymatic activity. The activity can also be changed by the reduction of the cofactor glutathione, a reducing agent that can be decreased by mercury. Moreover, increased reactive oxygen species (ROS) production, eventually caused by mercury, could lead to the oxidation of both thiol group and selenocysteine, thus reducing deiodinase activity $(11,12)$.

While the effects of Met-Hg have been widely studied, little is known about the effects of thimerosal on biological systems. Most of the information about the thimerosal in literature is based on extrapolations of the knowledge regarding methylmercury molecule. However, especially in developing countries, the population is exposed to numerous medications containing thimerosal, which could lead to irreparable damage to health. Thus, this work aimed to understand how thimerosal could interfere with the peripheral metabolism of thyroid hormones, with a special focus on the central nervous system.

\section{Materials and methods}

\section{Animals}

In all experiments, adult ( 2 months old) female Wistar rats were kept in a controlled temperature $\left(22-25^{\circ} \mathrm{C}\right)$ and $12 \mathrm{~h} / 12 \mathrm{~h}$ light/dark cycle (lights on 07:00-19:00h) animal room. Pelleted commercial chow (Paulinea, São Paulo, Brazil) and water were available ad libitum. The Institutional Committee for Use of Animals in Research approved the study (number: IBCCF196-07/16), and the procedures were in compliance with the International Guiding Principles for Biomedical Research Involving Animals of the Council for International Organizations of Medical Sciences (Geneva, Switzerland), and the guiding principles for care and use of animals from the American
Physiological Society. Each animal received 0.25 or $250 \mu \mathrm{g}$ of thimerosal per $100 \mathrm{~g}$ body weight, intramuscular, dissolved in saline solution twice a week for a month. Control animals received intramuscular injections of saline solution. The lower dose was chosen based on the one that a one-year-old child receives in a vaccine dose (13). The higher one was chosen based on concentrations previously used in vaccines for children in Denmark during the period of 1970-1992 (14). Cerebellum, hypothalamus, cerebral cortex, hippocampus, pituitary, liver and kidney were excised after treatment, immediately frozen in liquid nitrogen, and stored at $-80^{\circ} \mathrm{C}$ for mRNA extraction and deiodinase and $\mathrm{H}_{2} \mathrm{O}_{2}$ generating activities measurement. Blood was collected and serum was stored at $-20^{\circ} \mathrm{C}$ for thyroid hormone measurements.

Serum $\mathrm{T}_{3}$ and $\mathrm{T}_{4}$ were determined by specific Coated Tube RIA kits (Diagnostic Systems Laboratories Inc., TX, USA). Intra- and interassay coefficients of variation for $\mathrm{T}_{3}$ were $5.0-6.5 \%$ and $4.2-6.0 \%$, respectively, and sensitivity was $4.3 \mathrm{ng} / \mathrm{dL}$. For $\mathrm{T}_{4}$, intra- and interassay coefficients of variation were $2.9-5.1 \%$ and $7.1-7.4 \%$ respectively, and sensitivity was $0.4 \mu \mathrm{g} / \mathrm{dL}$. All procedures were performed following the fabricant recommendations.

D1 activity was determined using methods previously published (15). Briefly, whole pituitary, $15 \mathrm{mg}$ of liver and $25 \mathrm{mg}$ of kidney were homogenized in $150 \mathrm{mM}$ sodium phosphate buffer containing $1 \mathrm{mM}$ EDTA, $250 \mathrm{mM}$ sucrose, and $10 \mathrm{mM}$ DTT $(\mathrm{pH}$ 6.9). Homogenates were incubated in duplicate for $1 \mathrm{~h}$ at $37^{\circ} \mathrm{C}$ with $1 \mu \mathrm{M} \mathrm{rT}$, freshly purified tracer ${ }^{125} \mathrm{I}$-labeled $\mathrm{rT}_{3}$ (Perkin-Elmer Life and Analytical Sciences, Boston, MA, USA), and $10 \mathrm{mM}$ DTT in $0.1 \mathrm{M}$ potassium phosphate buffer containing $1 \mathrm{mM}$ EDTA, pH 6.9. Total reaction volume was $300 \mu \mathrm{L}$. In our assay conditions, only D1 activity is measured since deiodinases activities were completely blocked in the presence of $100 \mathrm{mM}$ PTU, a specific D1 inhibitor. D1 final activity was expressed as the difference between the sample activity and its respective background. D2 activity was also determined by methods previously published (16). In short, $30 \mathrm{mg}$ from each tissue analyzed were homogenized in $0.1 \mathrm{M}$ sodium phosphate buffer containing $1 \mathrm{mM}$ EDTA, $0.25 \mathrm{M}$ sucrose, and $20 \mathrm{mM}$ dithiothreitol, $\mathrm{pH}$ 6.9. Homogenates $(30 \mu \mathrm{g}$ protein) were incubated, in duplicate, for $3 \mathrm{~h}$ at $37^{\circ} \mathrm{C}$ with $1 \mathrm{nM}$ $\mathrm{T}_{4}$, freshly purified tracer ${ }^{125} \mathrm{I}$-labeled $\mathrm{T}_{4}$ (PerkinElmer Life Sciences), $1 \mathrm{mM}$ PTU, and $20 \mathrm{mM}$ DTT in $0.1 \mathrm{M}$ sodium phosphate buffer containing $1 \mathrm{mM}$ EDTA, $\mathrm{pH}$ 6.9. Total reaction volume was $300 \mu \mathrm{L}$. In our assays conditions, only D2 activity was measured since deiodinase activities were completely blocked in the presence of $\mathrm{T}_{4}$ in excess

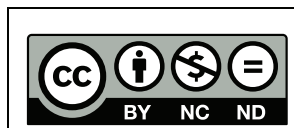

This work is licensed under a Creative Commons Attribution-NonCommercial-NoDerivatives 4.0 International License. 
Table 1 Primers used for real time PCR analysis.

D1
D2
$\beta$-Actin

\begin{tabular}{l} 
Foward \\
\hline 5' GTGATACAGGAAGGCAGGATC 3' \\
5' CTCCTAGACGCCTACAAACAG 3' \\
5' CACTTTCTACAATGAGCTGCG 3'
\end{tabular}

\section{Reverse}

5' GAACGAAGGTCAAAGCTAAAGG 3

5' TGCTTCAGGATTGGACACG 3'

5' CTGGATGGCTACGTACATGG 3'
(100 nM). D2 final activity was expressed as the difference as the difference between the sample activity and its respective background. Protein was measured by Bradford method (17), after incubation of homogenates with $\mathrm{NaOH}$ $(2.5 \mathrm{M})$ for $30 \mathrm{~min}$ at room temperature.

$\mathrm{H}_{2} \mathrm{O}_{2}$ generation was quantified in the particulate fractions obtained from cerebellum, hypothalamus, cerebral cortex, hippocampus, pituitary, liver and kidney by the Amplex red/horseradish peroxidase assay (Molecular Probes, Invitrogen). In order to obtain the microsomal fraction, the homogenates from the tissues were centrifuged at $3000 \mathrm{~g}$ for $15 \mathrm{~min}$ at $4^{\circ} \mathrm{C}$. Then, the supernatants were centrifuged at $100,000 \boldsymbol{g}$ for $35 \mathrm{~min}$ at $4^{\circ} \mathrm{C}$ and the pellets were suspended in $0.5 \mathrm{~mL}$ of $50 \mathrm{mM}$ sodium phosphate buffer, $\mathrm{pH} 7.2$, containing $0.25 \mathrm{M}$ sucrose, $2 \mathrm{mM} \mathrm{MgCl}_{2}, 5 \mathrm{mg} / \mathrm{mL}$ aprotinin and $34.8 \mathrm{mg} / \mathrm{mL}$ phenylmethanesulfonyl fluoride (PMSF) and stored at $-20^{\circ} \mathrm{C}$ until the analyses were performed. For $\mathrm{H}_{2} \mathrm{O}_{2}$ generation measure, the microsomal fraction was incubated in $150 \mathrm{mM}$ sodium phosphate buffer ( $\mathrm{pH} 7.4$ ) containing SOD (100 U/mL; Sigma), horseradish peroxidase (0.5 U/mL, Roche), Amplex red (50 mM; Molecular Probes) and $1 \mathrm{mM}$ EGTA, in the presence or absence of $1 \mathrm{mM}$ $\mathrm{NADPH}$. The fluorescence was immediately measured in a microplate reader (Victor X4; PerkinElmer) at $30^{\circ} \mathrm{C}$, using wavelength excitation at $530 \mathrm{~nm}$ and emission at $595 \mathrm{~nm}$ (18). Specific NADPH oxidase activity was calculated by the differences between the activities in the presence and absence of NADPH and the specific enzymatic activity was expressed as nanomoles $\mathrm{H}_{2} \mathrm{O}_{2}$ per hour per milligram of protein $(\mathrm{nmol} / \mathrm{h} / \mathrm{mg})$. Protein concentration was determined by the Bradford assay (17).

Total RNA was extracted from the cerebellum, hypothalamus, cerebral cortex, hippocampus, pituitary, liver and kidney using the RNeasy Plus Mini Kit (Qiagen), following the manufacturer's instructions. After DNAse treatment, reverse transcription of $1 \mu \mathrm{g}$ RNA was followed by real time polymerase chain reaction (PCR), as previously described (19). $\beta$-Actin was used as an internal control. The specific oligonucleotides were purchased from Applied Biosystems (Table 1).

Results are expressed as the mean \pm s.E.M. and were analyzed by one-way ANOVA, followed by Bonferroni's multiple comparison test. To analyze $\mathrm{H}_{2} \mathrm{O}_{2}$ generation, a non-parametric data, Kruskal-Wallis test followed by Dunn's multi-comparison test was used. All analyses were performed using the Graphpad Prism software (version 5, Graphpad Software). A value of $P \leq 0.05$ was considered statistically significant.

\section{Results}

In fact only the highest dose of thimerosal affected serum levels of thyroid hormones. While the total serum $\mathrm{T}_{4}$ was increased (C: 2.73 $\pm 0.165 ; \mathrm{T}$ 0.25: 2.52 \pm 0.220 ; T 250: $3.30 \pm 0.208 \mu \mathrm{g} / \mathrm{dL}$ ) (Fig. 1A), the total serum $\mathrm{T}_{3}$ was

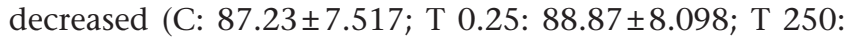
$29.66 \pm 10.11 \mathrm{ng} / \mathrm{dL}$ ) (Fig. 1B). This already suggested the decrease in peripherical $\mathrm{T}_{4}$ deiodination that we found (see below).

Only in highest thimerosal dose decreased D1 activity

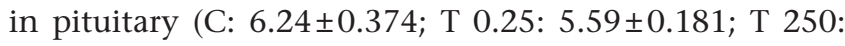
$2.71 \pm 0.541 \mathrm{pmolrT}_{3} / \mathrm{min} / \mathrm{mg}$ protein - Fig. 2A) and

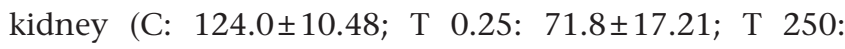
$39.7 \pm 14.62 \mathrm{pmolrT}_{3} / \mathrm{min} / \mathrm{mg}$ protein - Fig. $2 \mathrm{C}$ ), without affecting D1 activity in liver (Fig. 2E), although serum $\mathrm{T}_{3}$ is significantly decreased. D1 mRNA levels were unaffected in all tissues studied (Fig. 2B, D and F). Moreover, in all the tested tissues, thimerosal was able to directly inhibit D1 activity in vitro (Supplementary Fig. 1, see section on supplementary data given at the end of this article).
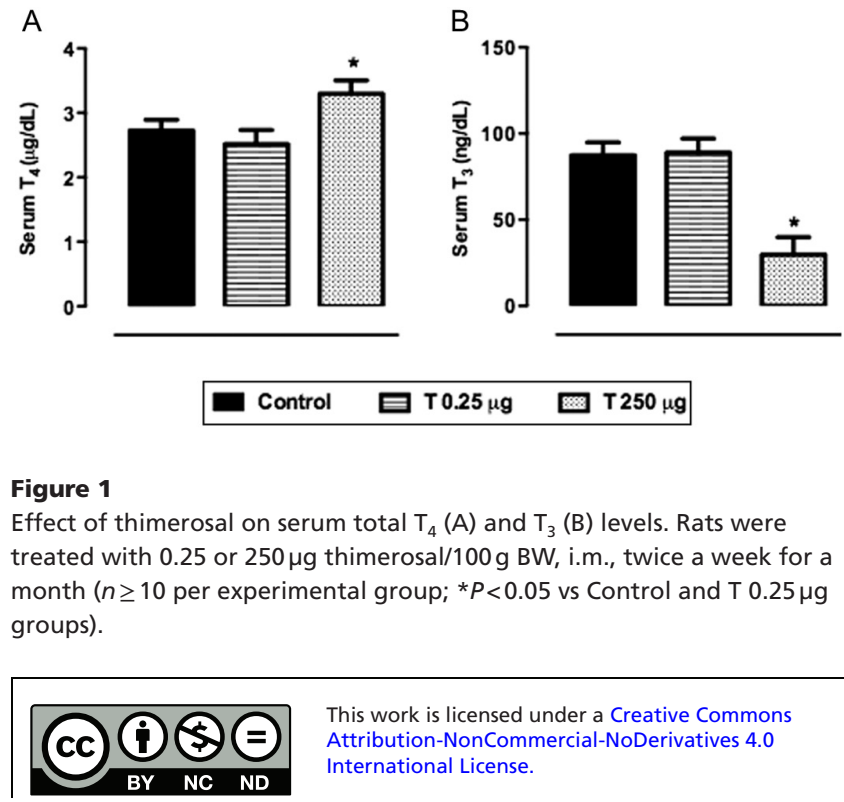

ontrol

$\mathrm{T} 0.25 \mu \mathrm{g}$ $\mathrm{T} 250 \mu \mathrm{g}$

Figure 1

Effect of thimerosal on serum total $T_{4}(A)$ and $T_{3}(B)$ levels. Rats were treated with 0.25 or $250 \mu \mathrm{g}$ thimerosal $/ 100 \mathrm{~g} \mathrm{BW}$, i.m., twice a week for a month ( $n \geq 10$ per experimental group; ${ }^{*} P<0.05$ vs Control and T $0.25 \mu \mathrm{g}$ groups). 

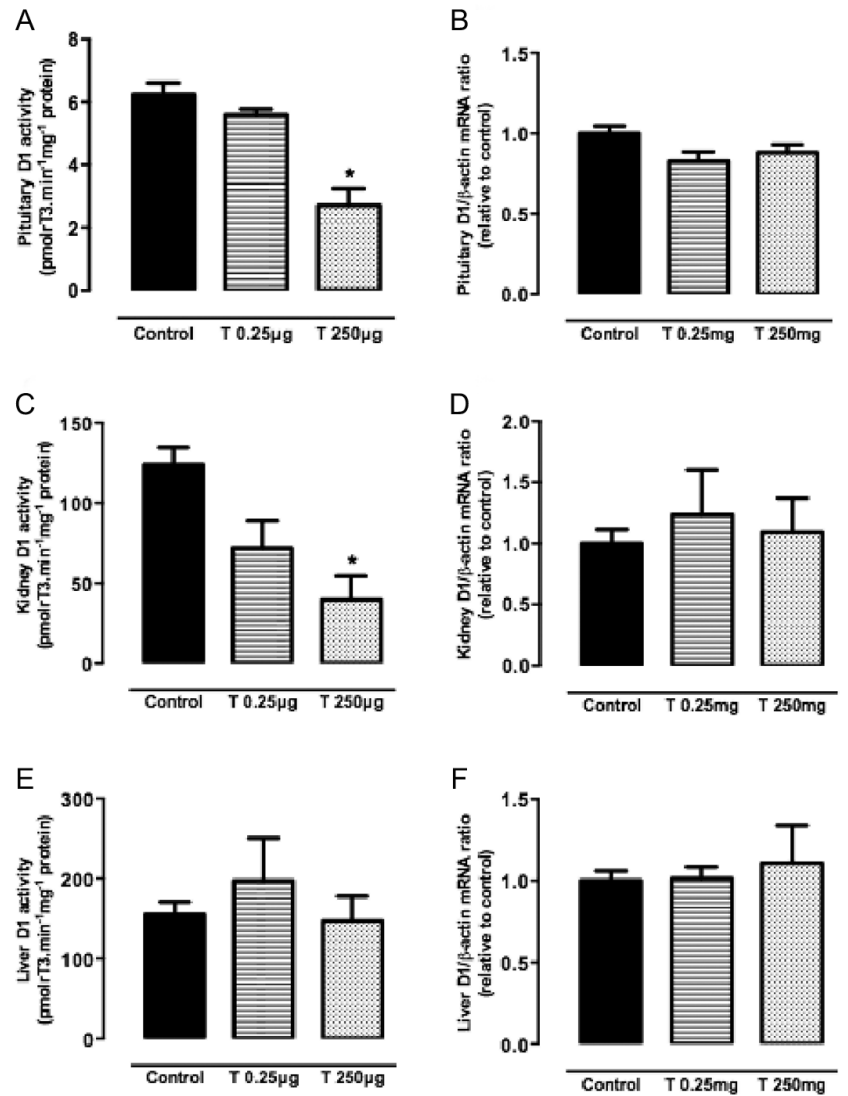

Figure 2

Effect of thimerosal on type 1 deiodinase activity and mRNA levels. D1 activity and mRNA levels were measured in pituitary (A and B), kidney ( $C$ and $D$ ) and liver ( $E$ and $F$ ), as indicated. Rats were treated with 0.25 or $250 \mu \mathrm{g}$ thimerosal $/ 100 \mathrm{~g} \mathrm{BW}$, i.m., twice a week for a month $(n=4-6$ animals per experimental group; ${ }^{*} P<0.05$ vs Control group).

D2 activity and mRNA expression in pituitary and hypothalamus are shown in Fig. 3. The highest dose of thimerosal treatment significantly decreased $\mathrm{D} 2$ activity in the pituitary (C: $0.52 \pm 0.071$; $\mathrm{T}$ 0.25: $0.37 \pm 0.059$; $\mathrm{T} 250$ : $0.21 \pm 0.033 \mathrm{fmol} \mathrm{T}_{4} / \mathrm{min} / \mathrm{mg}$ protein) (Fig. $3 \mathrm{~A}$ ) as well as in hypothalamus (C: $0.34 \pm 0.030 ; \mathrm{T} 0.25$ : $0.37 \pm 0.025$; $\mathrm{T} 250$ : $0.22 \pm 0.038 \mathrm{fmolT}_{4} / \mathrm{min} / \mathrm{mg}$ protein) (Fig. 3C). D2 mRNA expression were unaffected in both tissues (Fig. 3B and D).

The greater doses of thimerosal also decreased D2 enzymatic activity in the hippocampus (C: $0.25 \pm 0.035$; T 0.25: $0.25 \pm 0.030 ; \mathrm{T}$ 250: $0.15 \pm 0.014 \mathrm{fmol} \mathrm{T} / \mathrm{min} / \mathrm{mg}$ protein) (Fig. 4A) and in cerebral cortex (C: $0.17 \pm 0.053$; $\mathrm{T}$ 0.25: $0.17 \pm 0.054 ; \mathrm{T}$ 250: $0.06 \pm 0.013 \mathrm{fmolT}_{4} / \mathrm{min} / \mathrm{mg}$ protein) (Fig. 4C), although the later did not reach statistical significance. Neither cerebellar D2 activity, nor D2 mRNA in hippocampus, cerebral cortex or cerebellum were changed by thimerosal treatment (Fig. 4B, D, E and F). Moreover, in all tested tissues, thimerosal was able to directly inhibit D2 activity in vitro (Supplementary Fig. 2).
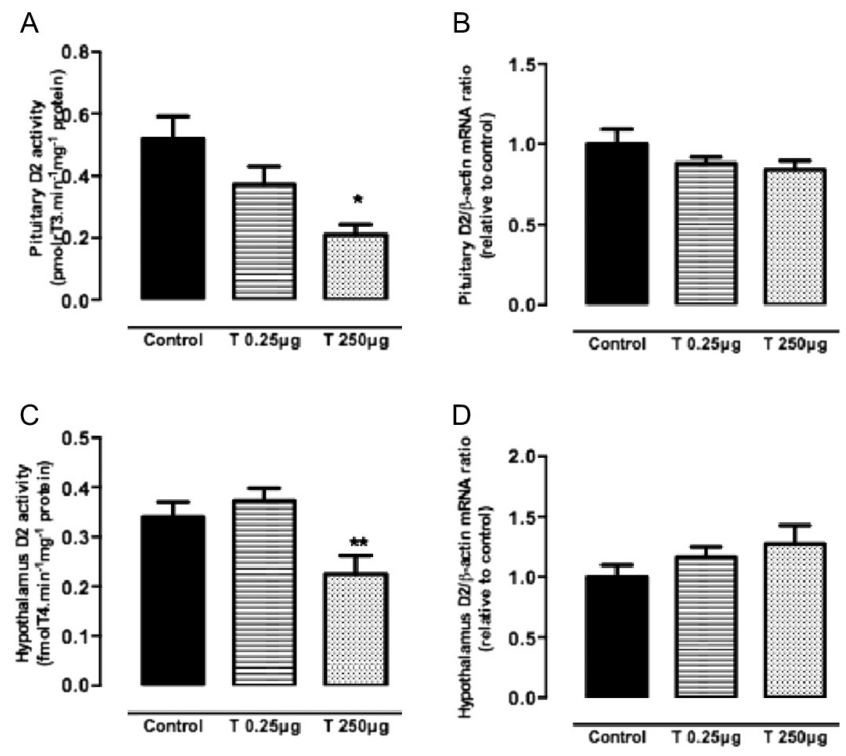

Figure 3

Effect of thimerosal on type 2 deiodinase activity and mRNA levels. D2 activity and mRNA levels were measured in pituitary (A and B) and hypothalamus ( $C$ and $D$ ), as indicated. Rats were treated with 0.25 or $250 \mu \mathrm{g}$ thimerosal $/ 100 \mathrm{~g} \mathrm{BW}$, i.m., twice a week for a month $(n=4-11$ animals per experimental group; ${ }^{*} P<0.05$ vs Control group; ${ }^{*} P<0.05$ vs T $0.25 \mu$ g group).

$\mathrm{H}_{2} \mathrm{O}_{2}$ generation activity in pituitary, kidney and liver is shown in Fig. 5. Pituitary $\mathrm{H}_{2} \mathrm{O}_{2}$ generation was decreased by both doses of thimerosal (C: $0.39 \pm 0.019$; $\mathrm{T} 0.25$ : $0.36 \pm 0.008$; T 250: $0.29 \pm 0.015 \mathrm{nmol}_{2} \mathrm{O}_{2} / \mathrm{h} / \mathrm{mg}$ protein). In the kidney $\mathrm{H}_{2} \mathrm{O}_{2}$ generation activity was decreased only at the highest dose $(\mathrm{C}: 0.39 \pm 0.020$; $\mathrm{T}$ 0.25: $0.34 \pm 0.014$; $\mathrm{T}$ 250: $0.15 \pm 0.022 \mathrm{nmol}_{2} \mathrm{O}_{2} / \mathrm{h} / \mathrm{mg}$ protein) (Fig. $5 \mathrm{~A}$ and $\mathrm{B}$ ), however the liver $\mathrm{H}_{2} \mathrm{O}_{2}$ generation remained unaffected by thimerosal treatment (Fig. 5C).

The $\mathrm{H}_{2} \mathrm{O}_{2}$ generation activities in hypothalamus (C: $\quad 0.25 \pm 0.016 ; \quad$ T $0.25: \quad 0.27 \pm 0.016 ; \quad$ T 250 : $0.20 \pm 0.012 \mathrm{nmol} \mathrm{H}_{2} \mathrm{O}_{2} / \mathrm{h} / \mathrm{mg}$ protein) and cerebral cortex (C: $0.30 \pm 0.016 ; \mathrm{T}$ 0.25: $0.34 \pm 0.025 ; \mathrm{T}$ 250: $0.12 \pm 0.025 \mathrm{nmol} \mathrm{H}_{2} \mathrm{O}_{2} / \mathrm{h} / \mathrm{mg}$ protein) were decreased by thimerosal but only at the greatest dose (Fig. 6A and B) without affecting hippocampal and cerebellar $\mathrm{H}_{2} \mathrm{O}_{2}$ generation activity (Fig. 6C and D).

\section{Discussion}

Thimerosal (TM) has been widely used as preservative in several drug products, including vaccines. However, it has been identified as a factor exerting a range of harmful neurological and cognitive effects in humans and has been implicated in the etiology of many neuropsychiatric disorders in children (20), even though these data were

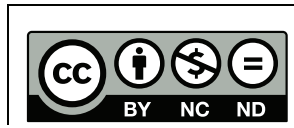

This work is licensed under a Creative Commons Attribution-NonCommercial-NoDerivatives 4.0 International License. 
A

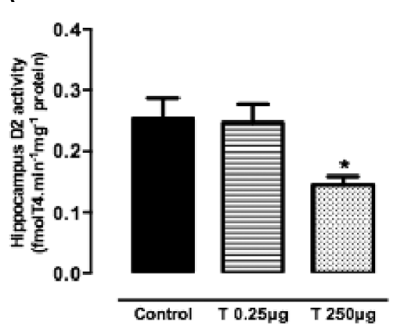

C

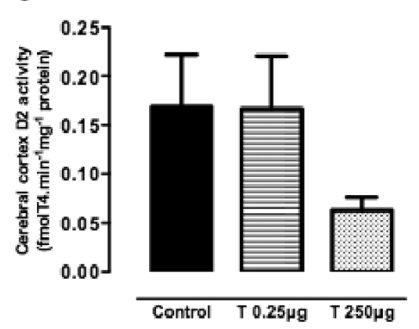

E

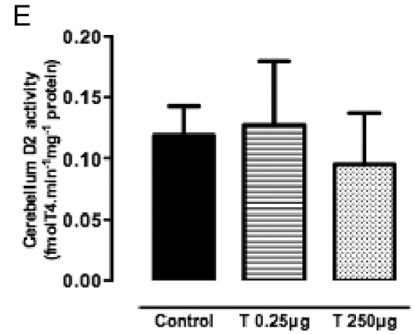

B
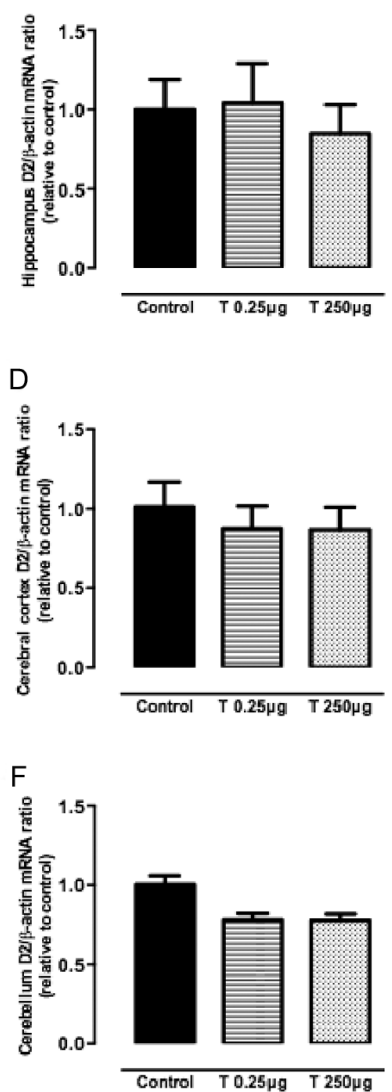

Figure 4

Effect of thimerosal on type 2 deiodinase activity and mRNA levels. D2 activity and mRNA levels were measured in hippocampus (A and B), cerebral cortex (C and D) and cerebellum ( $E$ and $F$ ), as indicated. Rats were treated with 0.25 or $250 \mu \mathrm{g}$ thimerosal $/ 100 \mathrm{~g} \mathrm{BW}$, i.m., twice a week for a month ( $n=3-10$ animals per experimental group; ${ }^{*} P<0.05$ vs Control group).

not confirmed in infant rhesus macaques following the recommended paediatric vaccination procedure (21). Although the use of mercury compounds, such as $\mathrm{TM}$ in antiseptic medicines is decreasing, it is still used as preservative in some vaccines mainly in developing countries. Herein, we compared two different TM doses, the lower $(0.25 \mu \mathrm{g} / 100 \mathrm{~g}$ BW) was based on the $2001 \mathrm{US}$ immunization schedule (13) and the higher $(250 \mu \mathrm{g} / 100 \mathrm{~g}$ BW) was based on concentrations previously used in vaccines for children in Denmark during the period of 1970-1992 (14), Since the lower dose did not produce any relevant effect on the vast majority of the parameters evaluated, our data suggests that only the higher dose could possibly be associated with neuropsychiatric disorders related to changes in thyroid hormones metabolism in children.

Thyroid hormones (TH) play a critical role during brain development and differentiation in humans and
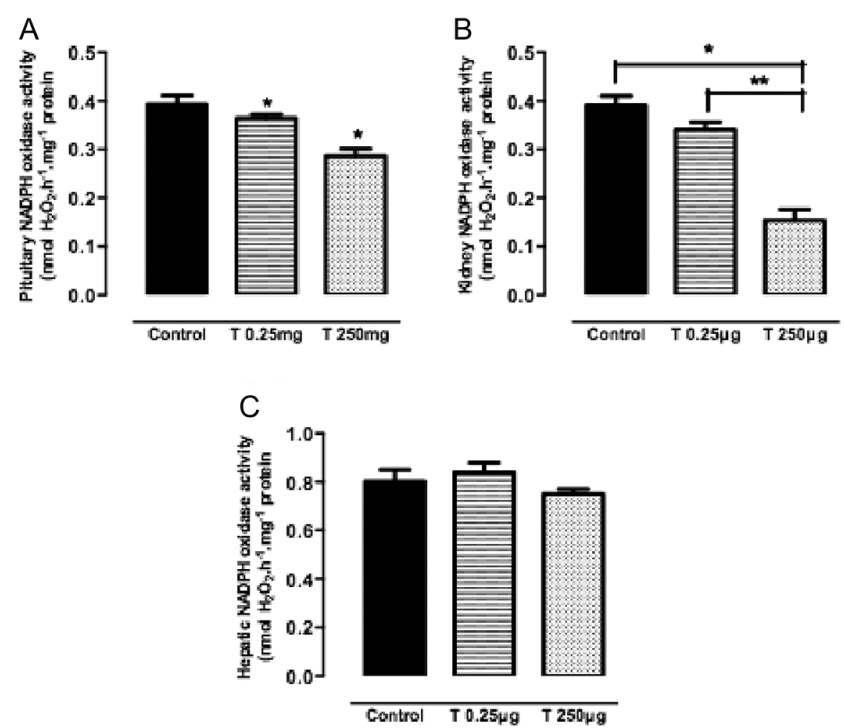

Figure 5

Effect of thimerosal on $\mathrm{H}_{2} \mathrm{O}_{2}$ generation. NADPH oxidase activity was measured in pituitary (A), kidney (B) and liver (C), as indicated. Rats were treated with 0.25 or $250 \mu \mathrm{g}$ thimerosal $/ 100 \mathrm{~g} \mathrm{BW}$, i.m., twice a week for a month ( $n=5-7$ animals per experimental group; ${ }^{*} P<0.05$ vs Control group; $* * P<0.05$ vs $\mathrm{T} 0.25$ group).

animal models (22). Much of the information known about thyroid hormones and brain development has derived from rodent experiments. Deiodinases regulate
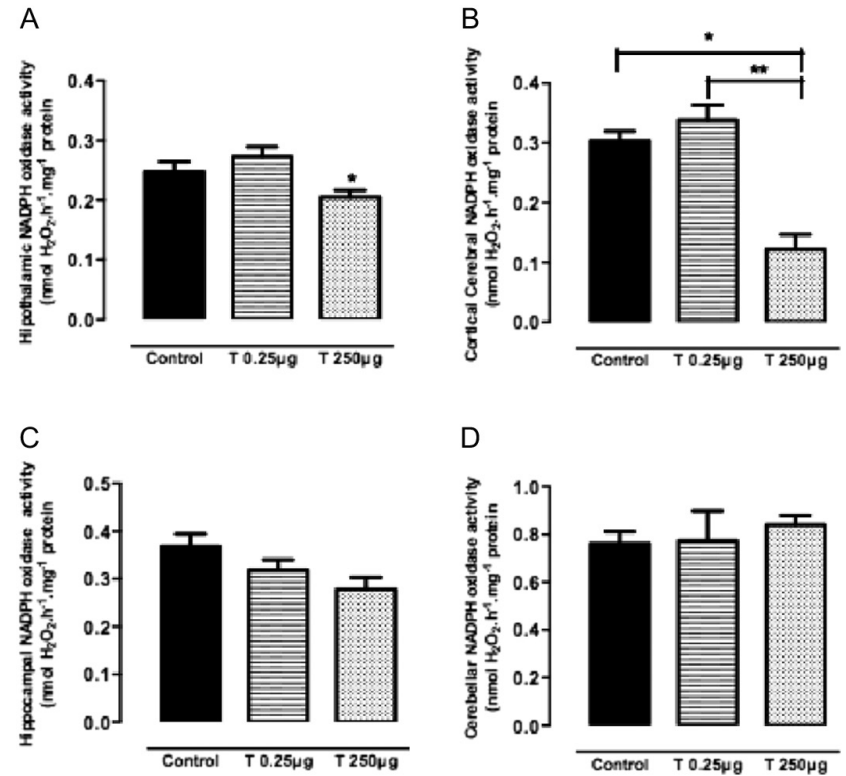

Figure 6

Effect of thimerosal on $\mathrm{H}_{2} \mathrm{O}_{2}$ generation. $\mathrm{NADPH}$ oxidase activity was measured in hypothalamus (A), cerebral cortex (B), hippocampus (C) and cerebellum (D), as indicated. Rats were treated with 0.25 or $250 \mu \mathrm{g}$ thimerosal/100 $\mathrm{g} \mathrm{BW,} \mathrm{i.m.,} \mathrm{twice} \mathrm{a} \mathrm{week} \mathrm{for} \mathrm{a} \mathrm{month}(n=3-6$ animals per experimental group; ${ }^{*} P<0.05$ vs Control group; ${ }^{*} P<0.05$ vs T 0.25 group).

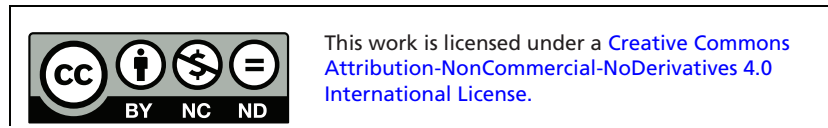


the metabolism of thyroid hormones and thus, regulate the concentration of these hormones in the different tissues (6). D1 and D2 are selenocysteine-containing enzymes that catalyze the deiodination of the prohormone thyroxine $\left(\mathrm{T}_{4}\right)$ into the active hormone triiodothyronine $\left(\mathrm{T}_{3}\right)$, both in central and peripheral tissues. In the brain, the major part of nuclear and intracellular $\mathrm{T}_{3}$ is locally produced from $\mathrm{T}_{4}$ by D2. Perinatal exposure to thimerosal can exert neurotoxic effects on the developing cerebellum and is associated with a decrease in D2 activity, which could result in local brain $\mathrm{T}_{3}$ deficiency. Our data in adult female Wistar rats show that TM treatment (at the highest dose) was able to inhibit D1 activity in pituitary and kidney, probably by directly binding to the selenium of the catalytic site, without affecting D1 mRNA expression in these tissues. Since the kidney is an important site for thyroid hormones metabolism, this inhibition might be involved in the decreased serum $\mathrm{T}_{3}$ levels associated with enhanced serum $\mathrm{T}_{4}$ levels detected after TM treatment in the present work. No statistically significant effect was detected in liver, neither in D1 activity nor mRNA levels, as could be expected by the decreased serum $\mathrm{T}_{3}$, what reinforces the idea that TM might directly act as an inhibitor of D1 in both pituitary and kidney.

D2 activity and mRNA levels were evaluated in pituitary, hippocampus, cerebellum, cerebral cortex and hypothalamus of adult female rats. We detected a decrease in D2 activity induced by TM at the highest dose of treatment in most tissues studied, except in cerebellum. On the other hand, no changes were detected in D2 mRNA levels in the studied tissues. In fact, Carneiro and coworkers evaluated the deposition and metabolism of mercury species in mice after exposure to TM (23). The authors showed marked mercury species accumulation in tissues such as brain and kidney, where we have detected decreased D2 and D1 activities respectively. Since we have found that TM was able to inhibit D1 and D2 activities both in vivo and in vitro, without changes in the mRNA levels of the enzymes, we think that this might be due to a direct interaction of TM with the protein(s) involved in the deiodination activity. It is tempting to suggest that TM might interact with the selenocysteine of the active site of deiodinases, or with the in vivo enzyme cofactor, even though the cofactor is in excess in the in vitro assays.

The affinity of mercury to thiol groups (-SH) makes peptides and proteins vulnerable to its inhibition, especially when sulfhydryl groups are in the active site of the enzyme. Thioredoxin system plays a key role in many physiological processes. It has been demonstrated that inhibition of thioredoxin system is one of the main mechanisms of $\mathrm{Hg}^{2+}$ and $\mathrm{MeHg}$ toxicity. This system is responsible for maintaining the general reduced state in cells and represents a potential biomarker of mercury toxicity (24). Thus, the reduced capacity of this system due to TM could be involved in the inhibitory effect on deiodinases, which require a reducing factor (probably glutathione) to catalyze deiodination reaction.

The effect of mercurial compounds on immune system is still controversial. Haase and coworkers demonstrated that ethylmercury and $\mathrm{Hg}^{+2}$ induce the formation of neutrophils extracellular traps (NETs) by human neutrophils granulocytes (25). This effect was triggered by ROS production in a NADPH oxidase independent way, since a NADPH oxidase inhibitor, did not abolish this effect. These results are in agreement with the present work, since we did not find any increment in NADPH oxidase activity. Increased oxidative stress was previously associated with the inhibition of D1 (26), but herein we did not detect any association between increased $\mathrm{H}_{2} \mathrm{O}_{2}$ generation and D1 activity. In fact, we have shown that at the highest dose $(250 \mu \mathrm{g} / 100 \mathrm{~g} \mathrm{BW})$, the treatment with thimerosal induced a decrease in $\mathrm{H}_{2} \mathrm{O}_{2}$ generation in pituitary, hippocampus, cerebral cortex and hypothalamus. Interestingly, D2 activity was also reduced in these same tissues. On the other hand, tissues in which $\mathrm{H}_{2} \mathrm{O}_{2}$ generation remained unchanged, such as cerebellum and liver, deiodinase activities were not affected too, thus suggesting a common cause for deiodinase and NADPH oxidase inhibition. The decrease in $\mathrm{H}_{2} \mathrm{O}_{2}$ generation in TM-treated rats does not seem to be due to a transcriptional effect of TM, since the mRNA levels of the ROS-generation enzymes, remained unaffected after thimerosal treatment in all tissues studied. In summary, our results indicate that TM (higher dose) inhibit D1 and D2 activities in some tissues, probably by binding to their selenium catalytic site, without altering their mRNA expression. NADPH oxidases are not involved in the diminished deiodinase activities, since the activity of these enzymes remained either unaltered or decreased. Our data contribute to increase the knowledge about the safety use of lower amounts of thimerosal and reinforces that low concentrations might be used in children vaccines.

\section{Supplementary data}

This is linked to the online version of the paper at http://dx.doi.org/10.1530/ EC-17-0220.

\section{Declaration of interest}

The authors declare that there is no conflict of interest that could be perceived as prejudicing the impartiality of the research reported.

This work is licensed under a Creative Commons Attribution-NonCommercial-NoDerivatives 4.0 International License. 


\section{Funding}

This work was supported by grants from the Fundação Carlos Chagas Filho de Amparo à Pesquisa do Estado do Rio de Janeiro (FAPERJ), (E26/110.609/2014) and the Conselho Nacional de Desenvolvimento Científico e Tecnológico (CNPq).

\section{Acknowledgments}

We are grateful for the technical assistance of José Humberto Tavares de Abreu, Norma Lima de Araújo Faria and Wagner Nunes Bezerra, at the Laboratório de Fisiologia Endócrina Doris Rosenthal, Instituto de Biofísica Carlos Chagas Filho, Universidade Federal do Rio de Janeiro.

\section{References}

1 Wiggers GA, Peçanha FM, Briones AM, Pérez-Girón JV, Miguel M, Vassalo DV, Cachofeiro V, Alonso MJ \& Salaices M. Low mercury concentrations cause oxidative stress and endothelial dysfunction in conductance and resistance arteries. American Journal of Physiology: Heart and Circulatory Physiology 2008295 H1033-H1043. (doi:10.1152/ajpheart.00430.2008)

2 Sulkowski ZL, Chen T, Midha S, Zavacki AM \& Sajdel-Sulkowska EM. Maternal thimerosal exposure results in aberrant cerebellar oxidative stress, thyroid hormone metabolism, and motor behavior in rat pups; sex- and strain-dependent effects. Cerebellum 201211 575-586. (doi:10.1007/s12311-011-0319-5)

3 Rizzetti DA, Torres JG, Escobar AG, Peçanha FM, Santos FW, Puntel RL, Alonso MJ, Briones AM, Salaices S, Vassallo DV, et al. Apocynin prevents vascular effects caused by chronic exposure to low concentrations of mercury. PLoS ONE $2013 \mathbf{8}$ e55806. (doi:10.1371/journal.pone.0055806)

4 Gomes FC, Lima FR, Trentin AG \& Moura-Neto V. Thyroid hormone role in nervous system morphogenesis. Progress in Brain Research 2001 132 41-50.

5 Crantz FR, Silva JE \& Larsen PR. An analysis of the sources and quantity of 3,5,3-triiodothyronine specifically bound to nuclear receptors in rat cerebral cortex and cerebellum. Endocrinology 1982 110 367-375. (doi:10.1210/endo-110-2-367)

6 Bianco AC \& Kim BW. Deiodinases: implications of the local control of thyroid hormone action. Journal of Clinical Investigation $2006 \mathbf{1 1 6}$ 2571-2579. (doi:10.1172/JCI29812)

7 Mori K, Yoshida K, Tani J, Hoshikawa S, Ito S \& Watanabe C. Methylmercury inhibits type II 5'-deiodinase activity in NB41A3 neuroblastoma cells. Toxicology Letters 2006161 96-101. (doi:10.1016/j.toxlet.2005.08.001)

8 Mori K, Yoshida K, Nakagawa Y, Hoshikawa S, Ozaki H, Ito S \& Watanabe C. Methylmercury inhibition of type II 5'-deiodinase activity resulting in a decrease in growth hormone production in GH3 cells. Toxicology 2007237 203-209. (doi:10.1016/j.tox.2007.05.012)

9 Watanabe C, Yoshida K, Kasanuma Y, Kun Y \& Satoh H. In utero methylmercury exposure differentially affects the activities of selenoenzymes in the fetal mouse brain. Environmental Research 1999 80 208-214. (doi:10.1006/enrs.1998.3889)

10 Croteau W, Davey JC, Galton VA \& Germain DL. Cloning of the mammalian type II iodothyronine diodinase. Journal of Clinical Investigation 199698 405-417. (doi:10.1172/JCI118806)

11 Yin Z, Milatovic D, Aschner JL, Syversen T, Rocha JB, Souza DO, Sidoryk M, Albrecht J \& Aschner M. Methylmercury induces oxidative injury, alterations in permeability and glutamine transport in cultured astrocytes. Brain Research 20071131 1-10. (doi:10.1016/j. brainres.2006.10.070)
12 Polunas M, Halladay A, Tjalkens RB, Philbert MA, Lowndes H \& Reuhl K. Role of oxidative stress and the mitochondrial permeability transition in methylmercury cytotoxicity. Neurotoxicology 20115 526-534. (doi:10.1016/j.neuro.2011.07.006)

13 Hornig M, Chian D \& Lipkin W. Neurotoxic effects of postnatal thimerosal are mouse strain dependent. Molecular Psychiatry 20049 833-845. (doi:10.1038/sj.mp.4001529)

14 Madsen KM, Lauritsen MB, Pedersen CB, Thorsen P, Plesner AM, Andersen PH \& Mortensen PB. Thimerosal and the occurrence of autism: negative ecological evidence from Danish populationbased data. Pediatrics 2003112 604-606. (doi:10.1542/ peds.112.3.604)

15 Marassi MP, Fortunato RS, Silva ACM, Pereira VS, Carvalho DP, Rosenthal D \& Corrêa da Costa VM. Thyroid function and type 1 iodothyronine deiodinase activity in pre-pubertal and adult rats: effect of sexual steroids. Journal of Endocrinology 2007192 121-130. (doi:10.1677/joe.1.06901)

16 Pantaleão TU, Mousovich F, Rosenthal D, Carvalho DP \& Corrêa da Costa VM. Effect of serum estradiol and leptin levels on thyroid function, food intake and body weight gain in female Wistar rats. Steroids 201075 638-642. (doi:10.1016/j.steroids.2010.03.009)

17 Bradford MM. A rapid and sensitive method for the quantification of microgram quantities of protein utilizing the principle of protein-dye binding. Analytical Biochemistry 197672 248-254. (doi:10.1016/00032697(76)90527-3)

18 Fortunato RS, Lima de Souza EC, Ameziane-el Hassani R, Boufraqech M, Weyemi U, Lagente-Chevallier O, Carvalho DP, Bidart JM, Schlumberger M \& Dupuy C. Functional consequences of dual oxidase-thyroperoxidase interaction at the plasma membrane. Journal of Clinical Endocrinology and Metabolism 201095 5403-5411. (doi:10.1210/jc.2010-1085)

19 Schmittgen TD \& Livak KJ. Analyzing real-time PCR data by the comparative CT method. Nature Protocols 20083 1101-1108. (doi:10.1038/nprot.2008.73)

20 Geier DA, King PG, Hooker BS, Dórea JG, Kern JK, Sykes LK \& Geier MR. Thimerosal: clinical, epidemiologic and biochemical studies. Clinica Chimica Acta 2015444 212-220. (doi:10.1016/j.cca.2015.02.030)

21 Gadad BS, Li W, Yazdani U, Grady S, Johnson T, Hammond J, Gunn H, Curtis B, English C, Yutuc V, et al. Administration of thimerosal-containing vaccines to infant rhesus macaques does not result in autism-like behavior or neuropathology. PNAS 2015112 12498-12503. (doi:10.1073/pnas.1500968112)

22 Patel J, Landers K, Li H, Mortimer RH \& Richard K. Thyroid hormones and fetal neurological development. Journal of Endocrinology 2011209 1-8. (doi:10.1530/JOE-10-0444)

23 Carneiro MFH, Souza JMO, Grotto D, Batista BL, Souza VCO \& Barbosa F Jr. A systematic study of the deposition and metabolism of mercury species in mice after exposure to low levels of thimerosal (ethylmercury). Environmental Research 2014134 218-227. (doi:10.1016/j.envres.2014.07.009)

24 Branco V, Ramos P, Canário J, Lu J, Holmgren A \& Carvalho C. Biomarkers of averse response to mercury: histopathology versus thioredoxin redutase activity. Journal of Biomedicine and Biotechnology 20122012 article ID 359879. (doi:10.1155/2012/359879)

25 Haase H, Hebel S, Engelhardt G \& Rink L. Ethylmercury and Hg² induce the formation of neutrophils extracellular traps (NETs) by human neutrophils granulocytes. Archives of Toxicology 201690 543-550. (doi:10.1007/s00204-015-1484-y)

26 Chen K, Yan B, Wang F, Wen F, Xing X, Tang X, Shi Y \& Le G. Type 1 5 '-deiodinase activity is inhibited by oxidative stress and restored by alpha-lipoic acid in HepG2 cells. Biochemical and Biophysical Research Communications 2016472 496-501. (doi:10.1016/j.bbrc.2016.02.119) http://www.endocrineconnections.org DOI: 10.1530/EC-17-0220 (c) 2017 The authors Published by Bioscientifica Ltd
Received in final form 29 September 2017

Accepted 5 October 2017

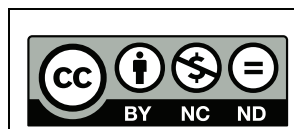

This work is licensed under a Creative Commons Attribution-NonCommercial-NoDerivatives 4.0 International License. 